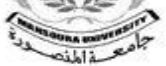

Mansoura University

Faculty of Tourism and Hotels

\title{
Assessment of FoOd HANDLINg ProcedURES IN MANSOURA UNIVERSITY HOSTELS
}

Extract of Master Thesis

\begin{abstract}
By
Ghada Mohamed Ali

Master Researcher

Faculty of Tourism and Hotels - Mansoura University

Dr/Mohammed Abd El-Fattah Zohry

Dr/Ahmed Hassan Metwaly

Lecturer of Hotel management-

Ass. Prof of Hotel management-

Faculty of Tourism and Hotels -

Mansoura University

Faculty of Tourism and Hotels Mansoura University
\end{abstract}




\section{Assessment of FoOd Handling Procedures in MANSOURA UNIVERSITY HOSTELS}

Ghada Mohamed Ali

Mohammed Abd El-Fattah Zohry ${ }^{2}$

Ahmed Hassan Metwaly ${ }^{3}$

\section{Abstract $^{4}$}

Increasing number of food poisoning outbreaks and food-related scares have led to call for better hygiene and quality practices. In the last few years, there have been a large number of cases of poisoning among students in university hostels, such as at Al-Azhar University. Food handling personnel are assumed to be responsible for most illnesses as a result of poor handling behavior at hostels. Food poisoning outbreaks of salmonella typhi, listeria monocytogenes and e-coli bacteria have made the students more skeptical of the food they eat. In university hostels, food handling procedures should be practiced by the correct and safely way during flow of food.

This research aims to assess food handling procedures in Mansoura university hostels. To achieve this objective, a food safety observation checklist was developed and adopted on six hostels from seven in Mansoura (one of them has been closed for maintenance during the period from March 2017 to June 2017) to identify to what extent the correct food handling procedures are followed. The list included sixty- three attributes covering receiving, storing, preparation, cooking, holding packaging ,transportation, pests control and food service process. For the observation checklist, a five point likert scale was used to evaluate the subattributes(Always- Often-Sometimes-Rarely-Never). The results of the research indicated that some of the investigated hostels often follow correctly food safety practices. Upon the research findings some recommendations were suggested to improve food handling procedures in the investigated university hostels such as; application of food safety practices during the food handling procedures, maintenance of equipments especially for the receiving process and establishing a separate department for food quality control within each university hostels.

Keywords:- Food Safety, University Hostels, Flow of Food. 
- Assessment of Food Handling Procedures in Mansoura University Hostels

\section{تقييم إجراءات تداول الأغذية في المدن الجاهعية بالمنصورة}

unil|

قد أدى تزايد عدد حالات التسهم الغذائي والخوف المتصل من الأغذية إلى الدعوة إلى تحسين مهارسات النظافة والنوعية أثناء تداول الغذاء. وِيْ السنوات القليلة الماضية كان هناك عدد كبير من حالات التسهم بين الطلاب يِ المدن الجامعية مثل

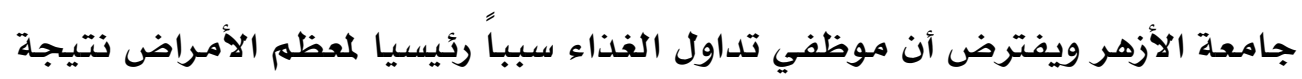
لسوء السلوكيات المتبعة ِيْ المدن الجامعية ، فالتسهمم الغذائي الناتج من البكتيريا

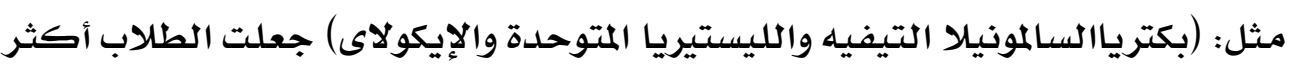

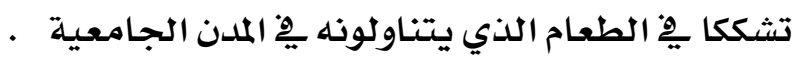
لذا يِّ المدن الجامعيـة يجب أن تتم إجراءات تداول الغذاء بطريقة صحيحة وآمنـه أثناء مـراحل دورة الغذاء. وتهدف هذه الدراسة إلى تقييه إجراءات تداول الأغذية بالمدن الجامعية بالتطبيق على جامعة المنصورة ولتحقيق هذا الهدف قام الباحثون بتصهيم استهـارة للمهلاحظة الشخصية تم تطبيقها على عينة من المدن الجامعية التابعة لجامعة المنصورة والتي بلغن عددها ستتة مدن جامعية مـن أصل سبعة مدن (حيث كانت هناك مدينة مغلقة نظراً لأعمال الصيانة) وذلك خلال الفترة من مارس IV إب وحتى يونيو IV لتححديد مدي تطبيق الإجراءات الصحيحة أثناء تداول الغذاء.وقد تضمنت استمارة الملاحظة الشخصية مجموعة من المتغيرات بلـغ عددها ثلاثة وستون متتغير شملت مـراحل دورة الغذاء حيث تم استخدام مقياس ليكرت الخماسي ( دائماًً - غالباً -

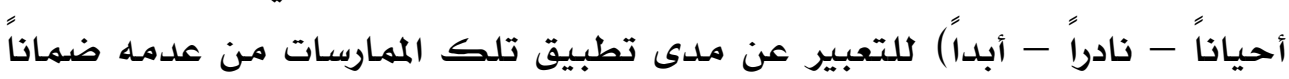
لسـلامـة الغذاء بـالمدن الجـامعية. وقد توصلت الدراسـة إلى أن بعض المدن الجامعية التي تم التحقق فيها غالبا مـا تتبـع الإجراءات الصحيحة مـع وجود بعض التوصيات لتتلافى بعض الأخطاء والتي ظهرت أثناء التقييم وذلك بغرض التحسين المستهر لمستوى الممارسات الخاصدة بتداول الأغذية بالمدن الجامعية ومنها : تطبيق الإجراءات 


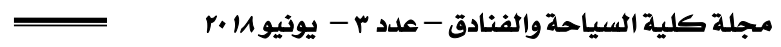

الصحيحة خلال جميع مراحل تداول الغذاء للتأكد من جودة وسلامهة الأغذية المقدمة ، عمل صيانة لكل المعدات الخاصدة بعملية الاستلام حيث وجدت يِ حالة سيئة ، إنشاء قسم منفصل لمراقبة جودة الأغذية و المشروبات داخل كل مدينة جامعية لضمان مستوي عالي من الجودة . الكامثمات الداله : سـلامهة الغذاء، المدن الجامعيلة و دورة الغذاء. 


\section{Introduction}

Omole ( 2001) stated that the university hostels is considered one of the most important non commercial institutions which provide accommodation, food and beverage services to a large number of students and with the increases of food poisoning cases in the last few years, attention should be paid to the food and beverage handling procedures at university hostels which it may affect positively or negatively on hostels and students.

According to Panisello and Quantick (2001) Food poisoning increases as a result of consumption of unwholesome food and a large number of food poisoning cases have been done among students in university hostels in the last few years, food handling personnel are assumed to be responsible for most illnesses as a result of poor handling behavior at hostels. Angelilo et al., (2000) argued that although food handling personnel played an important role in producing food for consumption, they were likely to contaminate the food by introducing pathogens in the procedures of flow of food .

Akonor and Akonor (2013) mentioned that the safety of food was considered as a public health problem that related to consumption of food and beverage, mainly caused by incorrect food handling practices. In fact, the World Health organization (WHO) (2007) recorded that up to $30 \%$ of people in developing countries suffered illnesses associated with consumption of food and beverage, hence pointing out that food safety was a main global problem .

\section{Problem of the Study}

The problem of this study lies on answering the following question:

1- To what extent Mansoura university hostels follow and adopt the correct food handling procedures?

\section{Aim of the Research}

This research aims to assess food handling procedures in Mansoura university hostels. To achieve this aim, these steps were followed :

1. Review the previous studies related to the research subject.

2. Identify to what extent Mansoura university hostels follow and adopt the correct food handling procedures .

3. Develop a set of recommendations based on the results of the field study through the observation checklist. 


\section{Literature of Review}

\section{Food Safety Concept}

Food-borne illnesses occurred due to breakdown in basic hygienic practices in the entire food flow from farm to fork Blanch (2003). Food safety in any establishment depended on food flow, which referred to how food was handled from purchasing and receiving through storing, preparation, cooking, holding, cooling, reheating and finally serving (National Restaurant Association Education Foundation,2004).

Hazard Analysis Critical Control Points system (HACCP) has long been internationally recognized and accepted as the system for effective food safety management (Panisello and Quantick, 2001). It is a systematic preventive approach to food safety for identifying potential contamination and subsequently evaluating the critical limits for each step. Its success and effectiveness in preventive food-borne diseases and reducing food safety risks to an acceptable level depends on its correct implementation (Kok , 2009).

Training and education are essential to ensure workers have adequate awareness and knowledge to comply with food safety requirements and the need for training of food handlers is an essential part of the HACCP concept(Dinana, 2014). Knowledge alone does not alter attitudes toward food safety (Yallow et al.., 2009).

The acceptance of food safety systems has put employees training under the microscope (Collins and Winnips , 2002). Under the personnel program of HACCP, employees must be trained in such areas as food safety, manufacturing controls and personnel hygiene (Williams, et al 2003). As well as, (MacAuslan ,2003) indicated that the majority of food establishments do not have satisfactory training policies for all their staff. Cenci-Goea et al., ( 2005) suggested that more emphasis and resources need to be diverted towards assistant managers to become highly motivated food hygiene managers who develop and maintain a food safety culture within their business.

From this vital point, more lodging establishments in Egypt where university hostels are one of them take into consideration to increase the awareness, knowledge and attitude of their employees towards food safety practices through conducting a specific food safety training programs to cover the different steps in food cycle (receiving, storing, preparation and cooking, holding and serving, pest control, personal hygiene and HACCP system) as mentioned by(Sharif et al., (2013). 


\section{University Hostels as a Food Service Establishment}

University hostel is referred to a place where students can stay when their residence is located far from the educational institution and which is considered essential to students' needs, which also called student housing ( Khozaei et al,2010).

According to Oxford Dictionary(2012), the definition of "hostel" in the Education Act and the regulations, and its management, must comply with the regulations. The definition covers a wide range of boarding establishments - for example, residential special schools, health camps, hostels operated by state and state integrated schools, and private hostels serving groups of international students attending registered university.

University hostels provide food and beverage services to students, which may directly affect their health in the case of contamination or unclean and with the increase in the number of students annually in the hostels and especially those who are far from their country, it was necessary to shed light on the services provided in hostels especially the food service (Foubert et al.,2003).

To make sure that the food is served in a proper and safe manner, food safety and sanitation must be built into and around the foodservice operation model (flow of food) (Medeiros et al., 2001).

\section{Research Methodology}

As mentioned previously, the aim of the present study is to assess the level of food handling procedures in university hostels applied to Mansoura university. For this purpose, a food safety observation checklist was developed and adopted on only six samples of Mansoura university hostels during the period from March 2017 to June 2017. The investigated samples of Mansoura university hostels are listed in table 1.

Table(1): The investigated samples of Mansoura university hostels

\begin{tabular}{|c|c|}
\hline No & University hostel name \\
\hline 1 & Al - Zahra university hostel \\
\hline 2 & Gihan university hostel \\
\hline 3 & Al-Amal university hostel \\
\hline 4 & Al-Galaa university hostel \\
\hline
\end{tabular}




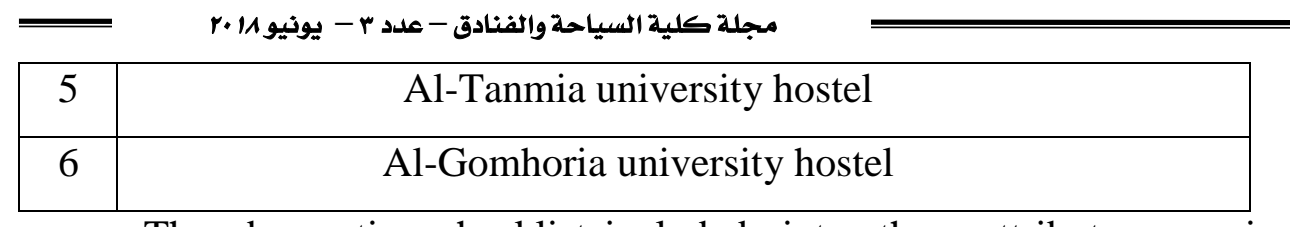

The observation checklist included sixty- three attributes covering three main sections , The first section intended to reveal the procedures that applied in receiving and storing process with its two types; dry and cold which cover twenty-five attributes. The second section intended to determine if the procedures of food preparation, cooking, holding and packaging processes were adopted correctly, this section involves sixteen attributes. Meanwhile, The third section consisted of twenty-two attributes among the transportation, service processes and pest control.

Each attribute was checked by using a five -point Likert-type scale (Always $=5$, Often $=4, \quad$ Sometimes $=3$, Rarely $=2$, and never $=1)$ to determine to what extent food safety practices are followed during food handling procedures.

\section{Results and Discussions}

The findings of the observation checklist were illustrated in the following tabulated data. As seen in Table (2) that represents the results of observation checklist which concern receiving ,storing and issuing practices, it could be noticed that none of the investigated hostels follow correctly all the receiving, storing and issuing food safety practices. Only sixteen attributes for example ( the receiving clerks follow good hygiene habits, all delivery vehicles are clean and in appropriate temperature, temperature checked with a calibrated thermometer to assure that cold foods are below $5 \mathrm{c}^{\circ}$ and frozen foods are below $-18 \mathrm{c}^{\circ}$ and the receiving equipment are available and in a good condition) out of twenty five were partially followed and seven attributes for example (the name of the food and lot identification has been provided, foods with out-dated expiration dates were rejected, the temperature of the stores are reasonable for the items stored, all goods are kept in clean and undamaged packs, the receiving clerks follow specific procedures to ensure quality and quantity control for each item and the storage clerk follows a first in, first out procedures during issuing process ) were followed by all of the investigatedproperties. 


\section{Table 2: Evaluation of Receiving, Storing and Issuing} Processes in the Investigated University Hostels

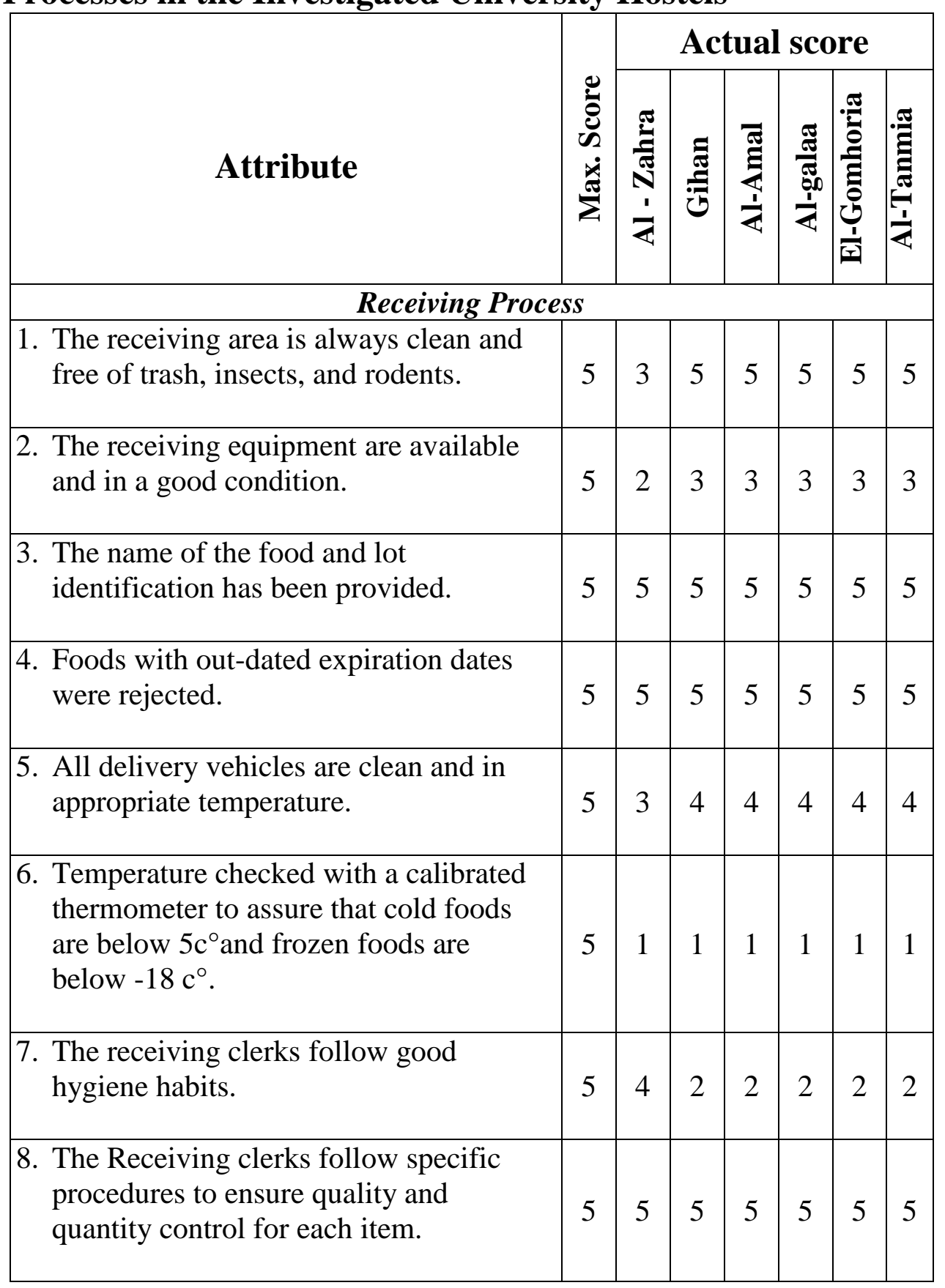




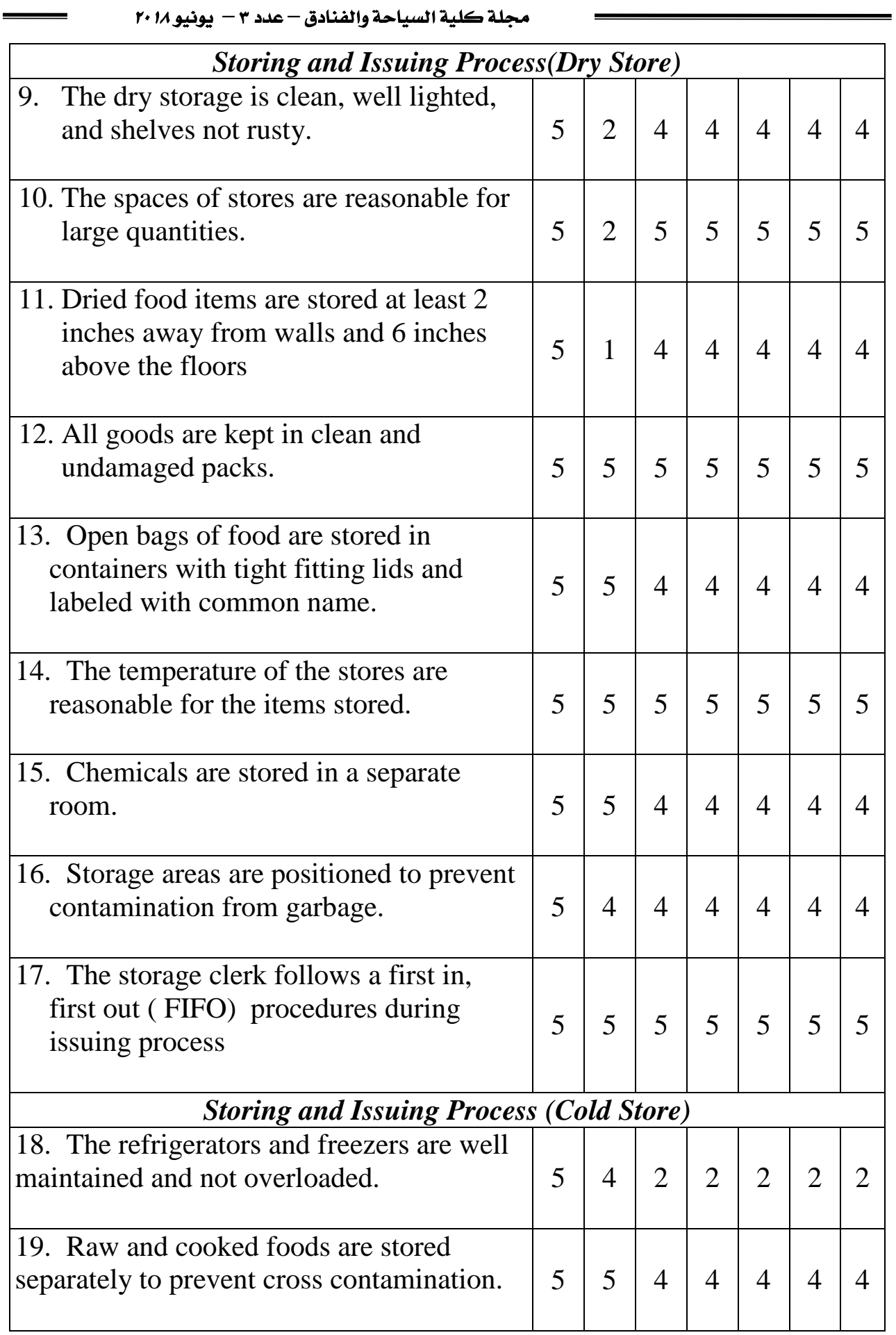




\begin{tabular}{|c|c|c|c|c|c|c|c|}
\hline $\begin{array}{l}\text { 20. Frozen and cold foods are kept } \\
\text { wrapped and in sanitary containers to } \\
\text { prevent freezing burns. }\end{array}$ & 5 & 3 & 3 & 3 & 3 & 3 & 3 \\
\hline $\begin{array}{l}\text { 21. The frozen and cold foods are placed } \\
\text { in a way that allows to cold air to circulate } \\
\text { properly. }\end{array}$ & 5 & 4 & 2 & 2 & 2 & 2 & 2 \\
\hline $\begin{array}{l}\text { 22. Proper chilling and freezing } \\
\text { procedures are applied. }\end{array}$ & 5 & 3 & 4 & 4 & 4 & 4 & 4 \\
\hline $\begin{array}{l}\text { 23. The proper temperature of the } \\
\text { refrigerator and freezers are maintained } \\
\left(4 \mathrm{c}^{\circ} \text { or lower for chillers and }-18 \mathrm{c}^{\circ} \text { for }\right. \\
\text { freezers }) \text {. }\end{array}$ & 5 & 2 & 4 & 4 & 4 & 4 & 4 \\
\hline $\begin{array}{l}\text { 24. Cooked and ready-to-eat foods are } \\
\text { stored above raw foods. }\end{array}$ & 5 & 4 & 4 & 4 & 4 & 4 & 4 \\
\hline $\begin{array}{l}\text { 25. A first in, first out (FIFO) procedure } \\
\text { is adopted for all freezing and refrigerated } \\
\text { items. }\end{array}$ & 5 & 5 & 5 & 5 & 5 & 5 & 5 \\
\hline Total Score & $\begin{array}{l}1 \\
2 \\
5\end{array}$ & $\begin{array}{l}9 \\
2\end{array}$ & $\begin{array}{l}9 \\
8\end{array}$ & $\begin{array}{l}9 \\
8\end{array}$ & $\begin{array}{l}9 \\
8\end{array}$ & $\begin{array}{l}9 \\
8\end{array}$ & $\begin{array}{l}9 \\
8\end{array}$ \\
\hline
\end{tabular}

As Table (2) showed some incorrect receiving, practices were followed - specially in Al-Zahraa university hostel - these practices may summarized as follow; the receiving equipment were in bad condition, all delivery vehicles weren't clean and inappropriate temperature, and there was no calibrated thermometer to assure that cold foods was below $5 \mathrm{c}^{\circ}$ and frozen foods are below $-18 \mathrm{c}^{\circ}$.

With regard to storing practices, nearly the same trend was observed. Dried food items were stored on the floor, dry stores were unorganized, chemicals were stored with food items, raw food were stored next to cooked one, calibrated thermometer was not used for checking temperature, and some of food items were not kept tightly wrapped or packaged. 


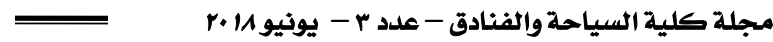

Table 3: Evaluation of Food Preparation ,Cooking, Holding and Packaging Processes in the Investigated University Hostels

\begin{tabular}{|c|c|c|c|c|c|c|c|}
\hline \multirow[b]{2}{*}{ Attribute } & \multirow[b]{2}{*}{ 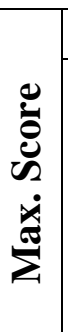 } & \multicolumn{6}{|c|}{ Actual score } \\
\hline & & 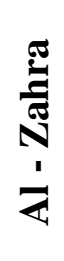 & 苞 & 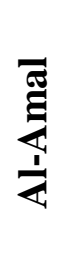 & 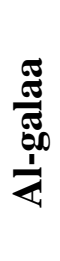 & 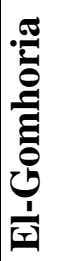 & 宸 \\
\hline \multicolumn{8}{|c|}{ Food Preparation and cooking Process } \\
\hline $\begin{array}{l}\text { 26. The preparation areas are always } \\
\text { clean, well lighted, and free from } \\
\text { insects and rodents. }\end{array}$ & 5 & 2 & 5 & 5 & 5 & 5 & 5 \\
\hline 27. Prepared foods are always covered. & 5 & 5 & 5 & 5 & 5 & 5 & 5 \\
\hline $\begin{array}{l}\text { 28. Food preparation and cooking } \\
\text { equipment, utensils, and food contact } \\
\text { surfaces are properly washed, rinsed, } \\
\text { and sanitized before every use }\end{array}$ & 5 & 3 & 5 & 5 & 5 & 5 & 5 \\
\hline $\begin{array}{l}\text { 29. Preparation is planned so ingredients } \\
\text { are kept out of the temperature } \\
\text { danger zone to the extent possible. }\end{array}$ & 5 & 5 & 5 & 5 & 5 & 5 & 5 \\
\hline $\begin{array}{l}\text { 30. Standardized quantity recipes are } \\
\text { adopted to keep quality and cost } \\
\text { control. }\end{array}$ & 5 & 5 & 5 & 5 & 5 & 5 & 5 \\
\hline $\begin{array}{l}\text { 31. Separate cooking utensils or an } \\
\text { individual dispensing method for } \\
\text { each food }\end{array}$ & 5 & 3 & 3 & 3 & 3 & 3 & 3 \\
\hline $\begin{array}{l}\text { 32. Food is cooked to the required safe } \\
\text { internal temperature for the } \\
\text { appropriate time. }\end{array}$ & 5 & 5 & 5 & 5 & 5 & 5 & 5 \\
\hline
\end{tabular}




\begin{tabular}{|c|c|c|c|c|c|c|c|}
\hline \multicolumn{8}{|c|}{$=\quad$ Assessment of Food Handling Procedures in Mansoura University Hostels } \\
\hline $\begin{array}{l}\text { 33. A calibrated thermometer used to } \\
\text { check product temperature }\end{array}$ & 5 & 1 & 1 & 1 & 1 & 1 & 1 \\
\hline \multicolumn{8}{|c|}{ Holding of Foods Process } \\
\hline 34. All holding units are clean. & 5 & 5 & 5 & 5 & 5 & 5 & 5 \\
\hline $\begin{array}{l}\text { 35. Hot holding units are not used to } \\
\text { reheat potentially hazardous foods. }\end{array}$ & 5 & 5 & 5 & 5 & 5 & 5 & 5 \\
\hline $\begin{array}{l}\text { 36. Temperature of hot food being held } \\
\text { is at or above } 60 \mathrm{c}^{\circ} \text {. }\end{array}$ & 5 & 4 & 5 & 5 & 5 & 5 & 5 \\
\hline $\begin{array}{l}\text { 37. Hot holding equipment does not use } \\
\text { to cook or reheat foods. }\end{array}$ & 5 & 5 & 5 & 5 & 5 & 5 & 5 \\
\hline \multicolumn{8}{|c|}{ Packaging Process } \\
\hline $\begin{array}{l}\text { 38. food protected from being } \\
\text { contaminated during the packaging } \\
\text { process }\end{array}$ & 5 & 2 & 3 & 3 & 3 & 3 & 3 \\
\hline $\begin{array}{l}\text { 39. packaging materials are suitable for } \\
\text { food contact purposes and unlikely to } \\
\text { contaminate food }\end{array}$ & 5 & 2 & 3 & 3 & 3 & 3 & 3 \\
\hline $\begin{array}{l}\text { 40. All food is properly wrapped, } \\
\text { labeled, and dated. }\end{array}$ & 5 & 2 & 5 & 5 & 5 & 5 & 5 \\
\hline $\begin{array}{l}\text { 41. Hot and cold foods are packaged } \\
\text { separately and in appropriate } \\
\text { temperature }\end{array}$ & 5 & 2 & 5 & 5 & 5 & 5 & 5 \\
\hline Total Score & $\begin{array}{l}8 \\
0\end{array}$ & $\begin{array}{l}5 \\
6\end{array}$ & $\begin{array}{l}7 \\
0\end{array}$ & $\begin{array}{l}7 \\
0\end{array}$ & $\begin{array}{l}7 \\
0\end{array}$ & $\begin{array}{l}7 \\
0\end{array}$ & 70 \\
\hline
\end{tabular}

Looking at the results in Tables (3), nearly the same trend was noticed that some of the investigated hostels could follow correctly all the preparation, cooking, holding and packaging food safety practices. As Table (3) showed only four attributes (prepared foods are always covered, preparation is planned so ingredients are kept out of the temperature danger zone to the extent possible, standardized quantity recipes are adopted to keep quality and cost control, and food is cooked to the required safe internal temperature for the appropriate time) in food preparation and cooking process and three attributes (all holding units are clean, hot holding 
units are not used to reheat potentially hazardous foods and hot holding equipment does not use to cook or reheat foods) in holding of food process out of sixteen attributes were followed and partially followed, respectively by all of the investigated hostels. Reviewing the results in the mentioned table, it could be noticed that a lot of incorrect food safety practices were followed. These practices could be summarized as follows; there was no separate cooking utensils or an individual dispensing method for each food, there was no calibrated thermometer used to check product, foods weren't protected from being contaminated during the packaging process and packaging materials weren't suitable for food contact purposes and unlikely to contaminate food .

\section{Table 4: Evaluation of Transportation, Service Processes and Pests Control in the Investigated University Hostels}

\begin{tabular}{|c|c|c|c|c|c|c|c|}
\hline \multirow[b]{2}{*}{ Attribute } & \multirow[b]{2}{*}{ 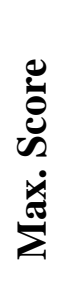 } & \multicolumn{6}{|c|}{ Actual score } \\
\hline & & $\frac{\mathfrak{J}}{\frac{\pi}{N}}$ & 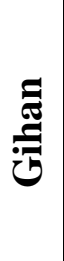 & 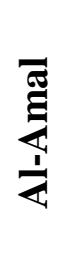 & 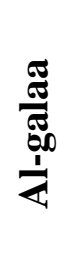 & 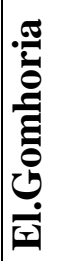 & 緎 \\
\hline \multicolumn{8}{|c|}{ Transportation Process } \\
\hline $\begin{array}{l}\text { 42. All delivery vehicles are clean and no } \\
\text { other materials are stored in the same } \\
\text { area as the food }\end{array}$ & 5 & 3 & 2 & 2 & 2 & 2 & 2 \\
\hline $\begin{array}{l}\text { 43. Batches of prepared food kept separate } \\
\text { during transportation. }\end{array}$ & 5 & 3 & 3 & 3 & 3 & 3 & 3 \\
\hline $\begin{array}{l}\text { 44. All foods are transported in controlled } \\
\text { temperature at all times. }\end{array}$ & 5 & 3 & 1 & 1 & 1 & 1 & 1 \\
\hline $\begin{array}{l}\text { 45. Foods are carried in tightly packages to } \\
\text { avoid contamination. }\end{array}$ & 5 & 3 & 3 & 3 & 3 & 3 & 3 \\
\hline \multicolumn{8}{|l|}{ Service Process } \\
\hline
\end{tabular}




\begin{tabular}{|c|c|c|c|c|c|c|c|}
\hline \multicolumn{8}{|c|}{$=\quad$ Assessment of Food Handling Procedures in Mansoura University Hostel } \\
\hline $\begin{array}{l}\text { 46. Serving utensils used with long handles } \\
\text { to keep hands away from the food item. }\end{array}$ & 5 & 5 & 5 & 5 & 5 & 5 & 5 \\
\hline $\begin{array}{l}\text { 47. Separate utensils used for each food } \\
\text { item. }\end{array}$ & 5 & 5 & 5 & 5 & 5 & 5 & 5 \\
\hline $\begin{array}{l}\text { 48. The hostel's restaurant was clean, } \\
\text { comfortable and visually appealing. }\end{array}$ & 5 & 5 & 4 & 5 & 3 & 5 & 4 \\
\hline $\begin{array}{l}\text { 49. Hot foods are served hot and cold } \\
\text { foods are served cold. }\end{array}$ & 5 & 5 & 5 & 5 & 4 & 5 & 5 \\
\hline $\begin{array}{l}\text { 50. Tables and chairs were clean, not worn } \\
\text { or damaged. }\end{array}$ & 5 & 5 & 4 & 4 & 3 & 5 & 4 \\
\hline $\begin{array}{l}\text { 51. Light fixtures and lamps were clean } \\
\text { and dust free. }\end{array}$ & 5 & 5 & 4 & 4 & 3 & 5 & 5 \\
\hline $\begin{array}{l}\text { 52. Chefs responded promptly to students' } \\
\text { requests. }\end{array}$ & 5 & 5 & 5 & 5 & 5 & 5 & 5 \\
\hline $\begin{array}{l}\text { 53. Employees appear neat and tidy (as } \\
\text { uniforms and personal grooming). }\end{array}$ & 5 & 3 & 4 & 4 & 4 & 5 & 5 \\
\hline 54. Employees appear in good health. & 5 & 4 & 3 & 4 & 5 & 5 & 5 \\
\hline $\begin{array}{l}\text { 55. Employees are always willing to serve } \\
\text { the students. }\end{array}$ & 5 & 5 & 3 & 5 & 5 & 5 & 5 \\
\hline 56. Staff are skillful and smiley. & 5 & 5 & 4 & 4 & 4 & 5 & 5 \\
\hline Pests Control & & & & & & & \\
\hline 57. There is no evidence of pests. & 5 & 4 & 4 & 4 & 4 & 5 & 4 \\
\hline $\begin{array}{l}58 . \\
\text {.here is a regular schedule of pest } \\
\text { control. }\end{array}$ & 5 & 4 & 5 & 5 & 5 & 5 & 4 \\
\hline
\end{tabular}




\begin{tabular}{|c|c|c|c|c|c|c|c|}
\hline \multicolumn{2}{|l|}{ 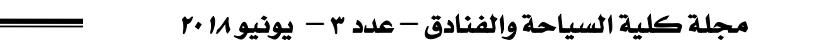 } & & & & & & \\
\hline $\begin{array}{l}\text { 59. Outside doors have screens, and are } \\
\text { equipped with a self-closing device. }\end{array}$ & 5 & 2 & 1 & 2 & 1 & 4 & 2 \\
\hline $\begin{array}{l}\text { 60. There is a contract with an approved } \\
\text { pest control company. }\end{array}$ & 5 & 3 & 5 & 5 & 5 & 4 & 4 \\
\hline $\begin{array}{l}\text { 61. Pest control tools and equipments are } \\
\text { available (i.e. air curtains , insect } \\
\text { killers...etc) }\end{array}$ & 5 & 1 & 1 & 1 & 1 & 3 & 1 \\
\hline 62. Garbage cans are emptied as necessary. & 5 & 5 & 5 & 5 & 5 & 5 & 5 \\
\hline $\begin{array}{l}\text { 63. Boxes and containers are removed } \\
\text { from site. }\end{array}$ & 5 & 5 & 5 & 5 & 5 & 5 & 5 \\
\hline Total Score & $\begin{array}{l}1 \\
1 \\
0\end{array}$ & $\begin{array}{l}8 \\
8\end{array}$ & $\begin{array}{l}8 \\
1\end{array}$ & $\begin{array}{l}8 \\
6\end{array}$ & $\begin{array}{l}8 \\
1\end{array}$ & $\begin{array}{l}9 \\
5\end{array}$ & $\begin{array}{l}7 \\
8\end{array}$ \\
\hline
\end{tabular}

The findings of the observation checklist are illustrated in the following tabulated data. As seen in Table (4) that represented the results of observation checklist which concern transportation, service and pest control practices, it could be noticed that none of the investigated hostels follow correctly all the food transportation, and pest control practices, a lot of incorrect food transportation and pest control practices were followed. These practices could be summarized as follows; all delivery vehicles weren't clean and other materials was stored in the same area with the food, all foods weren't transported in controlled temperature at all times, foods weren't carried in tightly packages to avoid contamination, pest control tools and equipments weren't available (i.e. air curtains , insect killers...etc), and outside doors weren't equipped with a self-closing device.

Reviewing the results in the mentioned table, it could be noticed that a lot of correct food safety practices in service process were followed. These practices could be summarized as follows; serving utensils used with long handles to keep hands away from the food item, separate utensils used for each food item, hot foods are served hot and cold food items served in suitable temperature .Chefs responded promptly to students' requests, and staff were skillful and smiley.

Table 5: Level of Application of the Correct Food Handling Procedures in the Investigated Hostels 


\begin{tabular}{|c|c|c|c|c|c|c|c|}
\hline \multirow{2}{*}{ 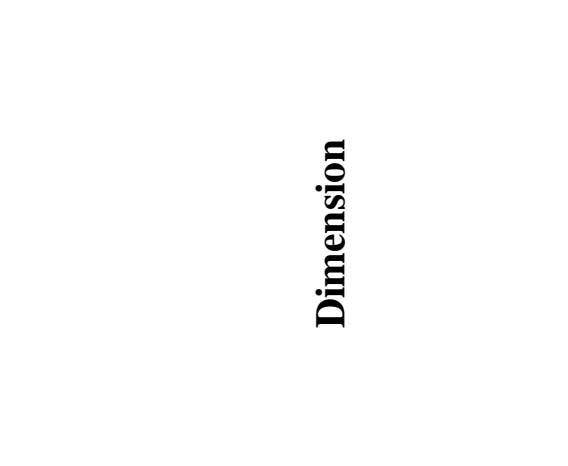 } & \multirow{2}{*}{ 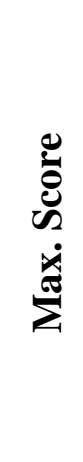 } & \multicolumn{2}{|c|}{$\sum \frac{\mathfrak{T}}{\stackrel{5}{\pi}}$} & \multicolumn{2}{|c|}{$\stackrel{\Xi}{\frac{1}{5}}$} & \multicolumn{2}{|c|}{ 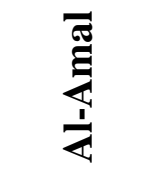 } \\
\hline & & 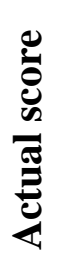 & 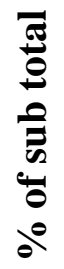 & 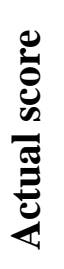 & $\begin{array}{l}\bar{\sigma} \\
\stackrel{5}{0} \\
0 \\
0 \\
0 \\
0 \\
0 \\
0 \\
0\end{array}$ & 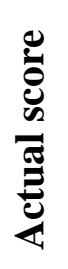 & $\begin{array}{l}\overline{\frac{\pi}{0}} \\
\frac{0}{0} \\
0 \\
\frac{0}{0} \\
\frac{0}{0} \\
0\end{array}$ \\
\hline $\begin{array}{c}\text { Receiving, Storing and Issuing } \\
\text { Processes }\end{array}$ & 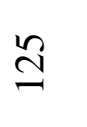 & สু & 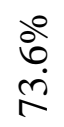 & $\infty$ & 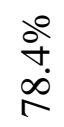 & $\infty$ & $\begin{array}{l}\infty \\
\substack{+\infty} \\
\substack{\infty \\
j}\end{array}$ \\
\hline $\begin{array}{c}\text { Food Preparation, Cooking, } \\
\text { Holding and Packaging } \\
\text { Processes }\end{array}$ & $\varnothing$ & ஜ & $\stackrel{\circ}{2}$ & $\stackrel{P}{P}$ & $\begin{array}{l}\infty \\
n \\
\infty \\
\infty\end{array}$ & $\stackrel{R}{R}$ & $\frac{i}{\infty}$ \\
\hline $\begin{array}{l}\text { Transportation, Service } \\
\text { Processes and Pests Control }\end{array}$ & $\stackrel{\varrho}{=}$ & $\infty$ & 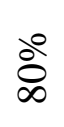 & $\infty$ & $\begin{array}{l}\dot{b} \\
\dot{2} \\
\dot{n}\end{array}$ & $\infty$ & $\frac{\substack{\infty \\
\infty}}{\infty}$ \\
\hline Total Score & $\frac{10}{2}$ & లై & $\frac{\Delta^{0}}{a^{+}}$ & 守 & $\frac{2}{8}$ & 茎 & $\begin{array}{l}\stackrel{8}{0} \\
\stackrel{0}{\infty}\end{array}$ \\
\hline$a b$ & & & & & & & \\
\hline
\end{tabular}




\begin{tabular}{|c|c|c|c|c|c|c|c|}
\hline \multicolumn{8}{|c|}{ مجلة كلية السياحة والفنادق - عدد r - يونيو 1 / r } \\
\hline \multicolumn{8}{|c|}{ Table 5 Continued } \\
\hline \multirow{2}{*}{ 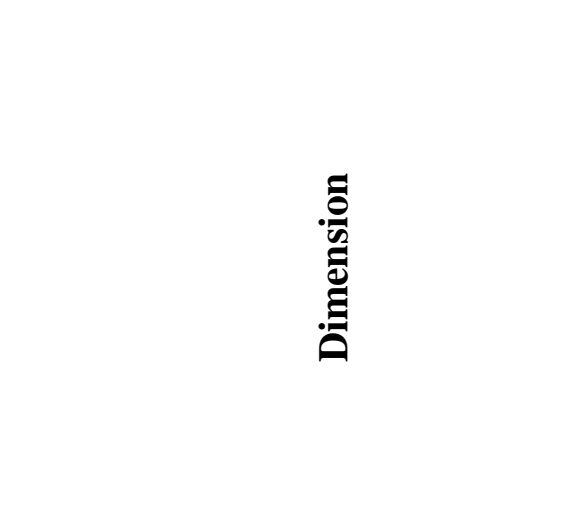 } & \multirow{2}{*}{ 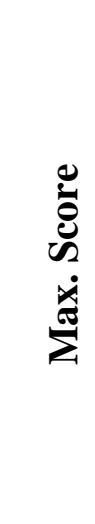 } & \multicolumn{2}{|c|}{ 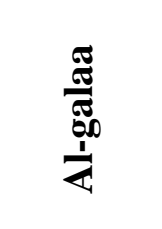 } & \multicolumn{2}{|c|}{ 穴 } & \multicolumn{2}{|c|}{ } \\
\hline & & 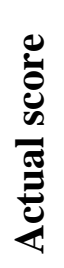 & 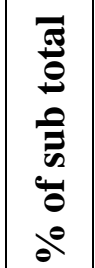 & 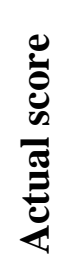 & 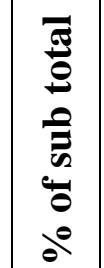 & 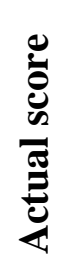 & 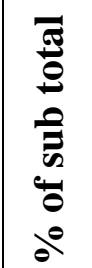 \\
\hline $\begin{array}{c}\text { Receiving, Storing and Issuing } \\
\text { Processes }\end{array}$ & $\cong$ & 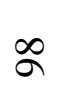 & $\mid \begin{array}{lll}i & 0 \\
\infty & 0 & 0\end{array}$ & $\stackrel{\infty}{\sigma}$ & 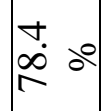 & $\stackrel{\infty}{\infty}$ & 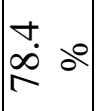 \\
\hline $\begin{array}{c}\text { Food Preparation,Cooking, } \\
\text { Holding and Packaging } \\
\text { Processes }\end{array}$ & $\infty$ & $尺$ & {$\left[\begin{array}{ll}n \\
\infty \\
\infty\end{array}\right]$} & 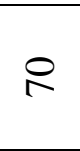 & $\frac{n}{\infty} b^{0}$ & & $\frac{n}{\infty} \infty$ \\
\hline $\begin{array}{l}\text { Transportation, Service } \\
\text { Processes and Pests Control }\end{array}$ & $\stackrel{ }{=}$ & $\bar{\infty}$ & $\begin{array}{l}\stackrel{b}{b} \\
\stackrel{2}{r}\end{array}$ & $n$ & $\begin{array}{l}\infty \\
\text { m̊ } \\
\infty\end{array}$ & $\infty$ & $\begin{array}{l}\stackrel{0}{8} \\
8 \\
\frac{1}{2}\end{array}$ \\
\hline Total Score & $\frac{n}{n}$ & 守 & 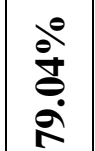 & $\ddot{\sim}$ & $\frac{\infty}{\dot{d}}$ & ஜn & $\frac{\circ}{\dot{\delta}}$ \\
\hline
\end{tabular}

Data in Table (5) summarized the level of food handling procedures achievements in the investigated hostels. As shown in the mentioned table it could be noticed that, Al-Gomhoria university hostel achieved the highest score in all investigated dimensions with $83.4 \%$. while Al-Tanmia and AlAmal university hostels represent $80.9 \%, 80.6 \%$ respectively, Gehan and Al-galaa university hostels represented the same score with $79.04 \%$, On the contrary, Al-Zahraa university hostel obtained the lowest score with $74.9 \%$. (Figure 1). 


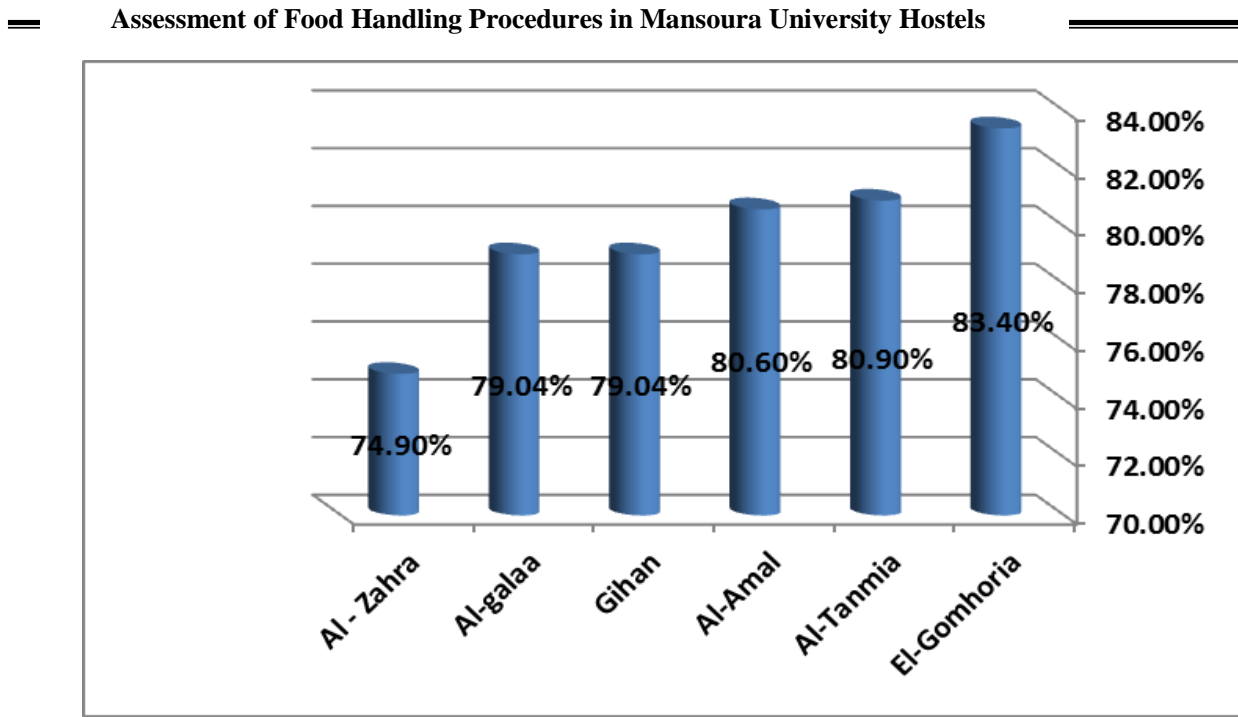

Figure1:Level of application of the correct food handling procedures in the investigated hostels

\section{Conclusion}

As a final conclusion, the university hostels management in the investigated sample should focus particular emphasis on following and adopting food safety practices in all food handling procedures. The study reflected a moderate level of food safety practices regarding Receiving, Storing and Issuing, Food preparation ,Holding, Packaging, Transportation, Service and Pest control .

\section{Recommendations}

Based upon both the literature reviewed and the field study findings, the following recommendations could be suggested:

\section{A)}

mproving the conditions of food handling procedures through :

- Application of the correct food safety practices during the food handling procedures to ensure the quality of food served.

- Frozen and cold foods should be kept wrapped and in sanitary containers to prevent freezing burns.

- Chemicals should be stored away from food and food related supplies.

- The food supervisors should be sure that the foods are kept out of the temperature danger zone of $(5-65)$ degrees cellicious by using calibrated thermometer to avoid food spoilage and poisoning.

- Concerning the packaging of foods, suitable packs should be made to keep the food temperature. 
- Transporting food in clean vehicles with a proper temperature and a good seal to avoid the food contamination from outside.

B)

mproving the conditions of stores, receiving area and equipment's through:

- Maintenance of equipment for the receiving process because most of the receiving equipment are in a bad condition.

- The refrigerators and freezers should be maintained .

- Setting aside suitable spaces for receiving, preparing and storing large quantities of food and they should be:

$\checkmark$ Clean and free of rodents and insects.

$\checkmark$ Good lighting, ventilation and proper temperature.

$\checkmark$ Equipped with tools and equipments in a good condition.

- For management and employees

- Improving the performance of production and serving employees through:

- Making on the job training courses periodically.

- Increasing the health awareness of employees and paying attention to personnel hygiene.

- Establishing a separate department for food quality control within each university hostel.

\section{Conclusion}

- As a final conclusion, the university hostels management in the investigated sample should focus particular emphasis on following and adopting food safety practices in all food handling procedures. The study reflected a moderate level of food safety practices regarding Receiving, Storing and Issuing, Food preparation ,Holding, Packaging, Transportation, Service and Pest control .

\section{Recommendations}

- Based upon both the literature reviewed and the field study findings, the following recommendations could be suggested:

- Improving the conditions of food handling procedures through :

- Application of the correct food safety practices during the food handling procedures to ensure the quality of food served.

- Frozen and cold foods should be kept wrapped and in sanitary containers to prevent freezing burns.

- Chemicals should be stored away from food and food related supplies. 
- The food supervisors should be sure that the foods are kept out of the temperature danger zone of $(5-65)$ degrees cellicious by using calibrated thermometer to avoid food spoilage and poisoning.

- Concerning the packaging of foods, suitable packs should be made to keep the food temperature.

- Transporting food in clean vehicles with a proper temperature and a good seal to avoid the food contamination from outside.

- Improving the conditions of stores, receiving area and equipment's through:

- Maintenance of equipment for the receiving process because most of the receiving equipment are in a bad condition.

- The refrigerators and freezers should be maintained .

- Setting aside suitable spaces for receiving, preparing and storing large quantities of food and they should be:

- Clean and free of rodents and insects.

- Good lighting, ventilation and proper temperature.

- Equipped with tools and equipments in a good condition.

- For management and employees

- Improving the performance of production and serving employees through:

- Making on the job training courses periodically.

- Increasing the health awareness of employees and paying attention to personnel hygiene.

- Establishing a separate department for food quality control within each university hostel.

${ }^{1}$ Research Master Thesis Faculty of Tourism and Hotels - Mansoura University

${ }^{2}$ Lecturer of Hotel management- Faculty of Tourism and Hotels - Mansoura University

${ }^{3}$ Ass. Prof of Hotel management- Faculty of Tourism and Hotels - Mansoura University 


\section{References}

- Akonor, P. T., and Akonor, M. A. (2013)." Food Safety Knowledge: The Case of Domestic Food Handlers in Ghana". Food Control Journal. 3(3),PP, 89-110.

- Angelillo, I. F., Viggiani, N. M. A., Rizzo, L. and Bianco, A.(2000). "Food Handlers and Food Borne Diseases: knowledge, Attitude, and Reported Behavior in Italy". Journal of Food Protection, 63(3) PP, 381- 402.

- Blanch, S. (2003). "Food Hygiene". London. Hodder and Stoughton Press,USA, PP.152-156.

- Cenci-Goea, B., Ortenzi, R., Bartocci, E., and Clementi, F. (2005). "Effect of the Implementation of HACCP on the Microbiological Quality of Meals at a University Restaurant". Journal of Food Borne Pathogens and Disease, 2 (1), PP: 138-154.

- Collins, B. and Winnips, K. (2002). "Two Scenarios for Productive Learning Environments in the Workplace". British Journal of Educational Technology, 33 (2), PP: 133-156.

- Dinana, R.T. (2014). Assessment of Food Safety and Food Hygiene Training Programs Adopted for Cooks in some Cairo Hotels via determining their Safety and Hygiene Knowledge. Egyptian journal of Tourism Studies, 13 (1), PP.50-70.

- Foubert, J. D., Tepper, R., and Morrison, D. R. (2003). "Predictors of Student Satisfaction in University Residence Halls". Journal of College and University Student Housing, 21 (1),PP, 41 - 46.

- Khozaei, F., Ayub, N., Hassan, A. S., and Khozaei, Z. (2010). "The Factors Predicting Students' Satisfaction with University Hostels, Case Study University Sains Malaysia". Asian Culture and History,2 (2), PP, $148-168$.

- Kok, D., Meally, A., Blair, I., McDowell, C. and Cowan, C. (2009). "Food Safety Knowledge of Head Chefs and Catering Managers in Ireland". Food Control Journal, 19 (1), PP, 291-319.

- MacAuslan, E. (2003). "The Boss, the Owner, the Proprietor, the Food Hygiene Manager? ".The Journal of the Royal Society for the Promotion of Health, 123 (4), PP,229-250. 
- Medeiros, L., Hillers, V., Kendall, P., and Mason, A. (2001). "Evaluation of Food Safety Education for consumers". Journal of Nutrition Education, 33 (1), PP.27-44.

- National Restaurant Association Educational Foundation. (2004). Servsafe coursebook (3rd ed.). Chicago, IL: Wiley,USA.

- Omole, F.K (2001). "Basic Issues in Housing Development", Femo Bless Publications, Ondo, Nigeria

- Oxford English

Dictionary(2012).(Available)http://www.Oxford.English Dictionary.com/.(Accessed on 15/8/2015)

- Panisello, P. and Quantick, P. (2001). "Technical Barriers to Hazard Analysis Critical Control Point". Food Control Journal, 12 (1), PP, 165-181.

- Sharif L, Obaidat MM, Al-Dalalah MR (2013):"Food Hygiene Knowledge, Attitudes and Practices of the Food Handlers in the University Hostels". Journal of Food and Nutrition Sciences. 19(4),PP,245-269.

- Williams, A., Smith, R., Gaze, R., Mortimore, S. and Wallace, C. (2003)."An International Future for Standards of HACCP Training". Food Control Journal, 14 (1), PP, 111-141.

- World Health Organization. (2007). Food safety and Food Borne Illness. Retrieved from :

http://www.who.int/mediacentre/factsheets/fs237/en/. (accessed in 15/8/2016)

- Yallow, L., Remig, M., and Higgins, M. (2009)." Food Safety Educational Intervention Positively Influences College Students' Food Safety Attitudes, Beliefs, Knowledge and Self-reported Practices". Journal of Environment Health, 71 (1), PP, 30-42. 